\title{
AGGREGATION OF SUBTROPICAL SOIL UNDER LIMING: A STUDY USING LASER DIFFRACTION ${ }^{(1)}$
}

\author{
Edson Campanhola Bortoluzzi ${ }^{(2)}$, Cristiano Poleto ${ }^{(3)}$, Álvaro José \\ Baginski $^{(4)} \&$ Vanderlei Rodrigues da Silva ${ }^{(5)}$
}

\begin{abstract}
SUMMARY
Laser diffraction (LD) provides detailed analysis of particle size distribution. Its application to testing the stability of soil aggregates can assist studies on the aggregation of soils with contrasting electrochemical properties. The objectives of the present work were: (a) to propose a protocol for using LD to study soil aggregation, (b) to study the aggregation of an Acrisol under the influence of different doses and forms of lime. Samples were collected in 2005 from a Brazilian Acrisol that in 1994 had received $0.0 ; 2.0 ; 8.5$ and $17.0 \mathrm{Mg} \mathrm{ha}^{-1}$ of lime, left on the soil surface or incorporated. Aggregates from 4.76 to $8.00 \mathrm{~mm}$ diameters were studied using the traditional method proposed by Kemper \& Chepil (1965), with wet sieving, while aggregates from 1.00 to $2.00 \mathrm{~mm}$ were studied using a CILAS ${ }^{\circledR}$ laser diffractometer that distinguishes particles ranging from 0.04 to $2,500.00 \mu \mathrm{m}$. LD readings were made after six consecutive pre-treatments, using agitation times, a chemical dispersion agent and ultrasound. Mean Weighted Diameter (MWD) and the Aggregate Stability Index (ASI) calculated, using the traditional method does not discriminate the treatments. However, LD is able to produce detailed data on soil aggregation, resulting in indexes of stability of aggregates that are linearly related to the doses of lime applied (MWD: $R^{2}=0.986$ and ASI: $R^{2}=0.876$ ). It may be concluded that electrochemical changes in the Brazilian Acrisol resulting from incorporated lime affect the stability of aggregates, increasing stability with increased doses of lime.
\end{abstract}

Index terms: laser granulometry, aggregate stability, particle cohesion.

\footnotetext{
(1) Received for publication in November 2008 and approved in February 2010.

(2) Professor at the Passo Fundo University UPF, Campus I, Zip Code: 99001-970, Passo Fundo, RS, Brazil. E-mails: edsonb@upf.br; edson.bortoluzzi@pq.cnpq.br

(3) Professor at the Federal University of Rio Grande do Sul - UFRGS. Bento Gonçalves Avenue, Zip Code: 91501-970, Porto Alegre, RS, Brazil. E-mail: cristiano_poleto@hotmail.com

(4) Undergraduate student at the Passo Fundo University UPF. PIBIC/Fapergs fellowshiper.

(5) Professor at the High Education Center in the Northern half of Rio Grande do Sul, Federal University of Santa Maria CESNORS/UFSM, Frederico Westphalen, RS, Brazil. Zip Code: 98400-000. E-mail: vanderlei@smail.ufsm.br
} 


\title{
RESUMO: AGREGAÇÃO DE UM SOLO SUBTROPICAL SOB CALAGEM: UM ESTUDO USANDO DIFRAÇÃO LASER
}

\begin{abstract}
A difração de raios laser (DL) oferece grande detalhamento da distribuição de tamanho de partículas. Sua aplicação em testes de estabilidade de agregados de solo pode auxiliar o estudo sobre a agregação de solos com propriedades eletroquímicas discrepantes. Nesse sentido, os objetivos do presente trabalho foram: propor um protocolo de uso da DL para estudar a agregação do solo; e estudar a influência de diferentes doses e formas de calagem sobre a agregação de um Argissolo. Amostras foram coletadas em 2005 em um Argissolo Vermelho Acinzentado distrófico plíntico que recebeu, em 1994, 0,0; 2,0; 8,5 e 17,0 $\mathrm{Mg} \mathrm{ha}^{-1}$ de calcário, incorporado na camada de 0,0-0,2 me deixado sobre a superfície do solo. Para isso, agregados com diâmetro entre 4,76 e 8,00 $\mathrm{mm}$ foram estudados utilizando o método tradicional proposto por Kemper e Chepil, com tamisamento em água, enquanto agregados com diâmetro entre 1 e $2 \mathrm{~mm}$ foram estudados utilizando um granulometro a laser CILA ${ }^{\circledR}$, que distingue partículas de 0,04 a 2.500,00 um de diâmetro. As leituras em DL foram feitas após seis pré-tratamentos consecutivos das amostras, utilizando para isso tempos de agitação, dispersante químico e ultrassom. O diâmetro médio ponderado (DMP) e o indice de estabilidade de agregados (IEA) pelo método tradicional não discriminaram os tratamentos. No entanto, a difração de raios laser é capaz de produzir dados detalhados sobre a agregação do solo, resultando em índices de estabilidade de agregados que se relacionam linearmente com as doses de calcário (DMP: $\mathrm{R}^{2}=$ 0,986 e IEA: $\mathrm{R}^{2}=0,876$ ). Concluiu-se que as modificações na eletroquímica de um Argissolo decorrentes da aplicação de calcário alteram a estabilidade dos agregados, aumentando-a com o incremento das doses de calcário.
\end{abstract}

Termos de indexação: granulometria por laser, estabilidade de agregado, coesão entre partículas.

\section{INTRODUCTION}

Soil aggregation is a physical property linked mainly to soil texture, soil structure and management practices (Castro Filho et al., 1998; Silva \& Mielniczuc, 1998; Reichert et al., 2003, 2006). Studies regarding soil aggregation produced with the aid of traditional methods, such as those proposed by Kemper \& Chepil (1965) lend support to this understanding (Albuquerque et al., 2003; Costa et al., 2004). Changes in the physical properties of soil have often been attributed to liming practices in an indirect way, due to greater root growth and biological activity, as well as to an increase in soil porosity through plowing during the incorporation procedure (Haynes \& Naidu, 1998; Albuquerque et al., 2003; Costa et al., 2004; Griève et al., 2005). Studies with traditional methods did not find evidences of the link between chemical amendments and the physical and hydraulic properties of soil (Veiga et al., 2008).

However, it is very well known that liming and fertilization alter soil electrochemistry, e.g. cation exchange capacity, $\mathrm{pH}$, base saturation, and many other soil chemical properties (Rheinheimer et al., 2000; Kaminski et al., 2005; Soratto \& Crusciol, 2008). Certain soil chemical properties are linked to the hydrophilic/hydrophobic character and cohesion/ dispersion forces between the soil particles (Prost et al., 1998; Albuquerque et al., 2003; Pernes-Debuyser \& Tessier, 2004; Chaplain et al., 2008). Changes in the physical properties of soil have been associated with electrochemical alterations in the soil, mainly in longterm experiments (Prost et al., 1998; Albuquerque et al., 2003; Pernes-Debuyser \& Tessier, 2004; Bortoluzzi et al., 2008a). Pernes-Debuyser \& Tessier (2004) have reported changes in the chemicophysical properties of a temperate soil in a long-term experiment as a response to different fertilizer sources.

The attempt at establishing a relationship between soil aggregation and changes in electrochemical properties due to soil liming seems to be very difficult using traditional methods. However, instrumental techniques such as laser diffraction (LD) provide detailed analysis of particle size distribution. This is a well-known method in granulometric studies of industrial materials and ocean and also for fluvial sediments (Hsieh, 1984; Beekman et al., 2005; Poleto et al., 2009), because it is a faster and more reliable method compared to traditional ones (Mudroch et al., 1996). Even though LD is not so commonly used in soil studies, it has proven to be reliable and effective when applied to soil mineralogy studies (Dur et al., 2004; Bortoluzzi et al., 2008b), and it can be used in more detailed studies of soil aggregation, because LD technique uses smaller aggregates and few mass of the samples (Muggler et al., 1997; Amézketa et al., 2003).

The purpose of this study is to better understand aggregation in an acidic subtropical soil in response to liming. It is reasonable to expect that the aggregate stability of the acidic soil may be affected by liming 
as a response to increases in the levels of $\mathrm{pH}, \mathrm{Ca}^{2+}$ and $\mathrm{Mg}^{2+}$, and decreases of $\mathrm{H}+\mathrm{Al}$ in the soils. These atributes are closely linked with cohesive forces among the soil particles (Le Bissonnais, 1996). However, in the traditional methods, there are two major drawbacks: first, macro-aggregation is more linked to soil management and mineralogical compounds; second, detailing of the aggregate granulometric classes is limited to the diameter of the mesh of the sieves used to separate them. By applying LD principles to measure the size of the aggregates, these limitations can be by-passed.

In this context, the present work has been carried out in order to: (a) propose a protocol for using the LD to study soil aggregation stability as an alternative to traditional methods, and (b) to study the aggregation of a Brazilian Acrisol under the influence of different doses and forms of lime.

\section{MATERIAL AND METHODS}

\section{Site and field experiment description}

An experiment conducted for 12 years on a soil under no-till conditions was chosen because of contrasting soil chemical properties due to doses and forms of liming. It is located in the experimental area of the Universidade Federal de Santa Maria (latitude $29^{\circ} 43^{\prime} 04$ " S and longitude $53^{\circ} 42^{\prime} 06$ ” W), in the State of Rio Grande do Sul, Brazil. The soil is a medium textured Argissolo according to Sistema Brasileiro de Classificação de Solos (Embrapa, 2006), Acrisol in the WRB (FAO, 2006) and Paleudalf in Soil Taxonomy (USDA, 1999). The soil developed a soft wavy relief on parental material originating from sandstone. The region has a humid subtropical climate with annual precipitation of 1,600 $\mathrm{mm}$, welldistributed throughout the year, and an annual average temperature of $19.2{ }^{\circ} \mathrm{C}$ with all four seasons well-defined (Moreno, 1961).

Plots measuring 12 × 12 m were delimited on an area covered by prairie, located on half the hillside, in 1994. Main plot treatments consisted of the distribution of lime doses over the soil, while in a subplot (half plot), the lime was incorporated using a single disk plow plus two diskings, with an approximate $0.20 \mathrm{~m}$ depth of soil disturbance. The doses of lime were 0.0, 2.0, 8.5 and 17.0 $\mathrm{Mg} \mathrm{ha}^{-1}$, and the dose of $2.0 \mathrm{Mg} \mathrm{ha}^{-1}$ was once again applied on soil surface two years after the first application $\left(2+2 \mathrm{Mg} \mathrm{ha}^{-1}\right)$. Since that time, the area has been cultivated in a no-till system using crop rotation: maize, soybeans, Italian ryegrass and white clover. Details of the experimental procedure and crop management procedures can be found in Rheinheimer et al. (2000) and Kaminski et al. (2005).

Physicochemical analysis of the soil, performed according to Tedesco et al. (1995) when installing the experiment, presented the following results for the layer from 0.0-0.2 m: clay content, $190 \mathrm{~g} \mathrm{~kg}^{-1}$; silt, $260 \mathrm{~g} \mathrm{~kg}^{-1}$; sand, $550 \mathrm{~g} \mathrm{~kg}^{-1}$; $\mathrm{pH}$ in water, 4.4; total organic matter content, $37 \mathrm{~g} \mathrm{dm}^{-3}$; exchangeable $\mathrm{Al}$, $3.30 \mathrm{cmol}_{\mathrm{c}} \mathrm{dm}^{-3}$; exchangeable $\mathrm{Ca}+\mathrm{Mg}, 3.7 \mathrm{cmol}_{\mathrm{c}} \mathrm{dm}^{-3}$; available $\mathrm{P}, 2.3 \mathrm{mg} \mathrm{dm}^{-3}$; and exchangeable $\mathrm{K}$, $54 \mathrm{mg} \mathrm{dm}^{-3}$. The SMP pH, buffered at $\mathrm{pH} 7.5$, was 4.5. This value corresponds to $17 \mathrm{Mg} \mathrm{ha}^{-1}$ of lime needed to increase the $\mathrm{pH}$ (water) of the soil to 6.0 (CQFSRS/SC, 2004). In 2005, undisturbed soil samples in the layer from $0.00-0.05 \mathrm{~m}$ were collected using $0.10 \mathrm{~m}$ diameter cores. An aliquot of soil $(<2 \mathrm{~mm})$ was submitted to a new chemical characterization following Tedesco et al. (1995) (Table 1).

Table 1. Chemical attributes and soil bulk density (Bd) for the 0.00-0.05 $\mathrm{m}$ soil layer under a no-till system as a function of lime doses and forms of application (lime left on soil surface and incorporated)

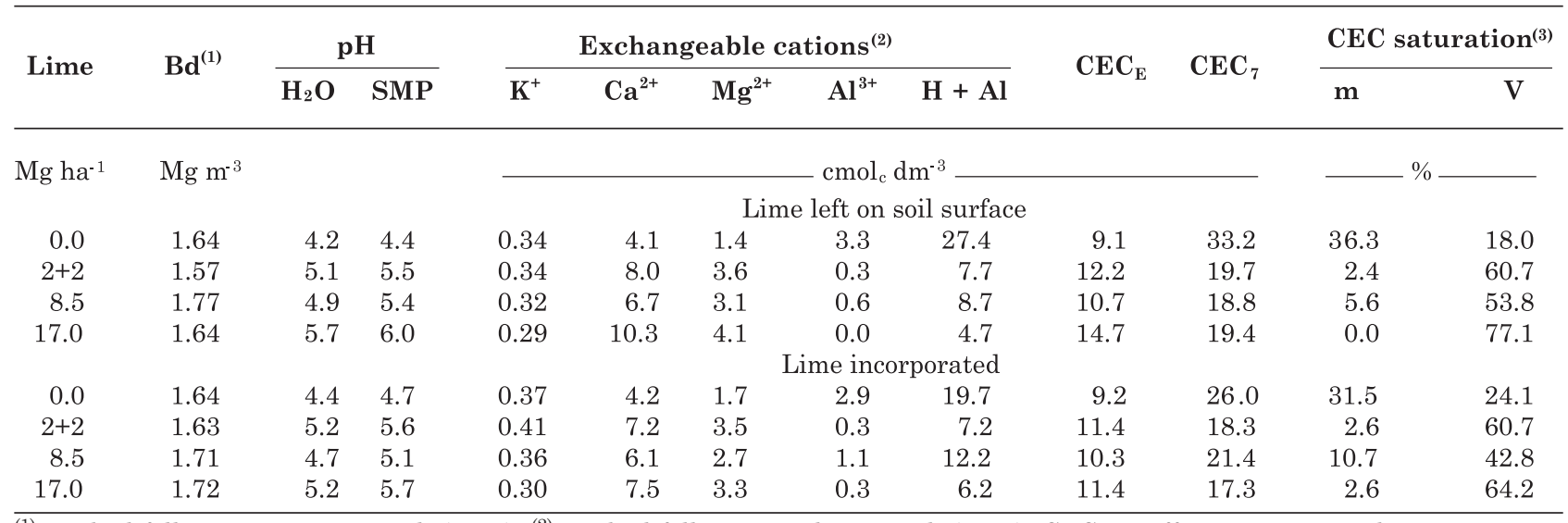

(1) Method following Monnier et al. (1973). (2) Method following Tedesco et al. (1995); $\mathrm{CEC}_{\mathrm{E}}$ is effective cation exchange capacity; $\mathrm{CEC}_{7}$ is cation exchange capacity at $\mathrm{pH}$ 7.0. ${ }^{(3)} \mathrm{m}$ (Al saturation) is the proportion of the exchangeable $\mathrm{Al}$ in $\mathrm{CEC}_{\mathrm{E}}$, and $\mathrm{V}$ (base saturation) is the proportion of the exchangeable bases in $\mathrm{CEC}_{7}$. 


\section{Soil physical analysis}

Material of the undisturbed samples originated aggregates and clods with a size between 3 and $6 \mathrm{~cm}^{3}$. The mass of the clods was determined in natural humidity, under immersion in kerosene and after drying at $105^{\circ} \mathrm{C}$ until constant weight. Following Monnier et al. (1973), the volume of the clods was determined, so, the soil bulk density can be calculated (Table 1).

The study of the aggregate stability by the traditional method was performed in the Land Use and Natural Resources Laboratory of the Universidade de Passo Fundo. Undisturbed samples were removed from their cores and sample aliquots were separated. Aggregates with a size between 8.00 and $4.76 \mathrm{~mm}$ were produced from larger clods with the aid of sieves and manual force from fingers. The technique of distribution of aggregates stable in water was performed in accordance with Kemper \& Chepil (1965) and Embrapa (1997), using an oscillation device described by Yoder (1936).

In summary, the analysis began with samples, in triplicates, with $15 \mathrm{~g}$ of aggregates, placed over a set of four sieves with meshes of 4.76, 2.00, 1.00 and $0.212 \mathrm{~mm}$. After slow wetting, the samples were submitted to constant vertical oscillation for $10 \mathrm{~min}$ at 42 movements per minute. The material retained was quantified in each sieve and was collected in a becker. The material that passed through the sieve mesh of $0.212 \mathrm{~mm}$ was determined by the difference between the mass of total samples and the mass retained on the sieves. The mass of the aggregates after drying at $105{ }^{\circ} \mathrm{C}$ was determined for material referring to the $6.36,3.38,1.50,0.605$ and $0.105 \mathrm{~mm}$ mean diameters.

The aggregation indexes determined were: the mean weighted diameter (MWD - Equation 1), the geometric mean diameter (GMD - Equation 2) and the aggregate stability index (ASI, \%).

$$
M W D=\sum_{i=l}^{n}\left(x_{i} \cdot w_{i}\right)
$$

where $\mathrm{w}_{\mathrm{i}}$ is the proportion of each class in relation to the total; $x_{i}$ is the mean diameter of the class $(\mathrm{mm})$;

$$
G M D=E X P \frac{\sum_{i=l}^{n} w_{p} \cdot \log x_{i}}{\sum_{i=l}^{n} w_{i}}
$$

where $\mathrm{w}_{\mathrm{p}}$ is the mass of each class.

The aggregation stability index is the ratio between the mass of the total sample and the mass of the sample retained in the $0.212 \mathrm{~mm}$ sieve mesh, expressed in percent.

The method for studying aggregate stability by laser diffraction was as follows. Aggregates with a size between 1.0 and $2.0 \mathrm{~mm}$ were separated using two sieves; the samples in three replicates were submitted to laser diffraction at several levels of mechanical, chemical and physical stresses. A CILAS $₫ 1180$ laser grain-size analyzer and Particle Expert ${ }^{\circledR}$ software were used, ranging from $0.04-2,500.00 \mu \mathrm{m}$, with three fibers and collimated laser diodes of 3 and $7 \mathrm{~mW}$, wavelength $\lambda=635$ and $830 \mathrm{~nm}$. In regard to operating conditions, samples were placed in a $500 \mathrm{~mL}$ water cell, lit by the low-intensity laser beam, and the scattered light was focused on the detectors by means of Fourier lens. The Fraunhofer or Mie theories were applied in the measurement of fine and coarse particles. The light scattering technique determines the radius of the particles and offers data in 95 fractions. Thus, the particles or aggregates in the samples are considered as spheres. The reflective index of the material was defined in a computer program in order to correspond to the soil samples. Details regarding the main technique are also found in Dur et al. (2004) and Bortoluzzi \& Poleto (2006).

Aggregates of $2 \mathrm{~g}$ of mass were dried at room temperature and placed in the cell of the LD apparatus, where measurements were carried out after the following stress pre-treatments: $1^{\text {st }}$; immediately after placing the aggregates inside the LD-cell containing deonized water; $2^{\text {nd: }}$ after one minute of agitation; $3^{\text {rd: }}$ after three minutes of agitation in the presence of $5 \mathrm{~mL}$ of Calgon ${ }^{\circledR} ; 4^{\text {th: }}$ : after one minute of agitation under ultrasound at $35 \mathrm{~W}$; $5^{\text {th: }}$ after two minutes of agitation under ultrasound at $35 \mathrm{~W} ; 6^{\text {th }}$ : after three minutes of agitation under ultrasound at $35 \mathrm{~W}$.

All pre-treatments were made successively and under constant agitation, and the last one was the most aggressive or intense, because it accumulated physicochemical and mechanical stress. A protocol for using LD for studying soil aggregation stability will be proposed following precision analysis (mean standard error) and the dynamic of aggregate size distribution after pre-treatment applications.

In order to study the effects of the lime doses and forms on aggregate size stability, the aggregation indexes were calculated for each level of stress or pretreatment, namely, the mean weighted diameter (MWD) and the aggregate stability index (ASI), except for the GMD that was not calculated for this method. The results were presented in diagrams, where aggregate size distributions are expressed in volume units. Anova analysis was carried out in a random block design, considering lime doses as the main treatment and forms of lime application as split-plots. The Tukey test was applied, and regression analyses were made for the quantitative data, whenever necessary. A Pearson correlation between chemical and physical parameters was also carried out on the data.

\section{RESULTS AND DISCUSSION}

\section{Soil aggregation studied by the traditional method (Kemper \& Chepil, 1965)}

Table 2 shows the values for structure stability determined by the Kemper \& Chepil (1965) method. 
There was no interaction between the treatments, i.e. lime doses and forms of application. The mean values of MWD, GMD and ASI were, respectively, 6.13, 2.12 and $97.4 \%$. These values were considered high compared to MWD for Red Latosols (Souza et al., 2009), but they were very similar to those found by Reichert et al. (2006) studying an Acrisol. As the MWD values found are very close to the modal diameter of the aggregates submitted to the test, the soil structure stability was considered high.

The lime forms and the doses applied in $1994 \mathrm{did}$ not affect the soil structure stability at the present time, due to soil management in a no-tillage system and crop rotation carried out during the experiment. As expected, the traditional method that uses the macro-aggregates (4.76 and $8.00 \mathrm{~mm}$ ) is not able to provide evidence of changes in soil aggregation due to different lime doses. These results reinforce the ones obtained by Castro Filho et al. (1998), and Costa et al. (2004) in studies of aggregate stability of Brazilian soils, and Veiga et al. (2008) in studies of soil hydraulic properties. Furthermore, the attempt at establishing a relationship between soil aggregation and changes in the electrochemical properties due to liming practices would be more promising with an LD method that uses micro-aggregates.

Laser diffraction as a method of studying soil aggregation stability

Figure 1 shows the proportion in percentage (v/v) of 95 classes of aggregate sizes by LD in only three levels of stress, i.e. first, third and sixth pretreatments, because they are representative of all pre-

Table 2. Mean Weighted Diameter (MWD), Geometric Mean Diameter (GMD) and Aggregate Stability Index (ASI) calculated following the Kemper \& Chepil (1965) method. The samples were aggregates between 4.76 $8.00 \mathrm{~mm}$ of an Acrisol at 0-0.05 $\mathrm{m}$ of depth, under liming in different doses and form of applications

\begin{tabular}{clll}
\hline Lime & MWD & GMD & ASI \\
\hline Mg ha $^{-1}$ & \multicolumn{2}{c}{ mm } & $\%$ \\
0.0 & 6.16 & 2.13 & 97.63 \\
$2+2$ & 6.09 & 2.11 & 97.64 \\
8.5 & 6.14 & 2.14 & 98.11 \\
17.0 & 6.08 & 2.08 & 96.37 \\
Mean & $6.13^{\text {ns }}$ & $2.12^{\text {ns }}$ & $97.44^{\mathrm{ns}}$ \\
CV (\%) & 1.70 & 2.75 & 35.29
\end{tabular}

ns: is not significant at $\mathrm{p}<0.05$ in Anova; CV: is the coefficient of variation of the interaction (dose $\mathrm{x}$ form of applications). Each mean is composed of six replications, regarding two forms of lime application (lime left on soil surface and incorporated). treatment stresses. In all the curves, it can be observed that the mean standard error was very small, demonstrating good precision among the laser diffraction observations. The modal diameter aggregate size (aggregate size value corresponding to the peak of the curve) varied according to the intensity of the applied stress, i.e., as the stress applied became cumulative and more intense, the modal diameter of the aggregates became smaller (Figure 1).

Measurements of the soil structure stability are based on the dynamics of diminishing aggregate sizes due to the application of mechanical and chemical stresses (Kemper \& Chepil, 1965; Le Bissonnais, 1996). Considering the levels of stress or pretreatments (Figure 1), it may be observed that the first two (1 $\left.1^{\text {st }}\right)$ and $\left(2^{\text {nd }}\right)$, with one and three minutes of agitation, presented similar modal diameters of aggregates for two lime forms and doses (only the first curve shown). However, in the third level of stress, the inclusion of Calgon $₫$ and agitation for three more minutes quickly decreased the modal diameters of the aggregates. On average the aggregate sizes diminished from 238 to $65 \mu \mathrm{m}$ in the lime left on the soil surface and from 229 to $98 \mu \mathrm{m}$ in lime incorporated in the soil. Using ultrasound, i.e. 4,5 and $6^{\text {th }}$ pretreatments, the modal diameters of the aggregates decreased more slowly, tending to be similar to each other after the first use of ultrasound (4th stress level), varying from 30 to $50 \mu \mathrm{m}$. Poleto et al. (2007) studied the use of ultrasound with different intensities and times, and they verified that the time under ultrasound, as compared to their intensity, did not seem to have an influence on the dispersion of samples. In this study, reduction of the modal diameters of the aggregates was observed, especially in the first to third and in the sixth stress level. Ultrasound did not promote greater changes in the modal diameters of aggregates, because its effects on the samples were accumulated with the others.

The laser diffraction protocol demonstrated that in addition to being precise, it is a powerful tool for studying soil aggregation. Observations from Muggler et al. (1997) confirmed that the LD techniques provide much more detailed information than classical methods in identifying particle size shifts.

The most effective pre-treatments in $\mathrm{LD}$ testing are those that use only agitation forces (1st and 2 nd stress levels) and chemical dispersant stress (3rd stress level). This interpretation is consistent with Dur et al. (2004), who verified that the precision and accuracy of the measurements in $\mathrm{LD}$ on dispersed soils were confirmed by observations in high resolution transmission electronic microscopy (HRTEM).

The methods presented certain peculiarities concerning the previous treatment of the samples and the mass and the initial size of the aggregates, as well as the type and duration of the applied stress. Methods such as the one suggested by Kemper \& Chepil (1965) are commonly used in Brazil in order to 


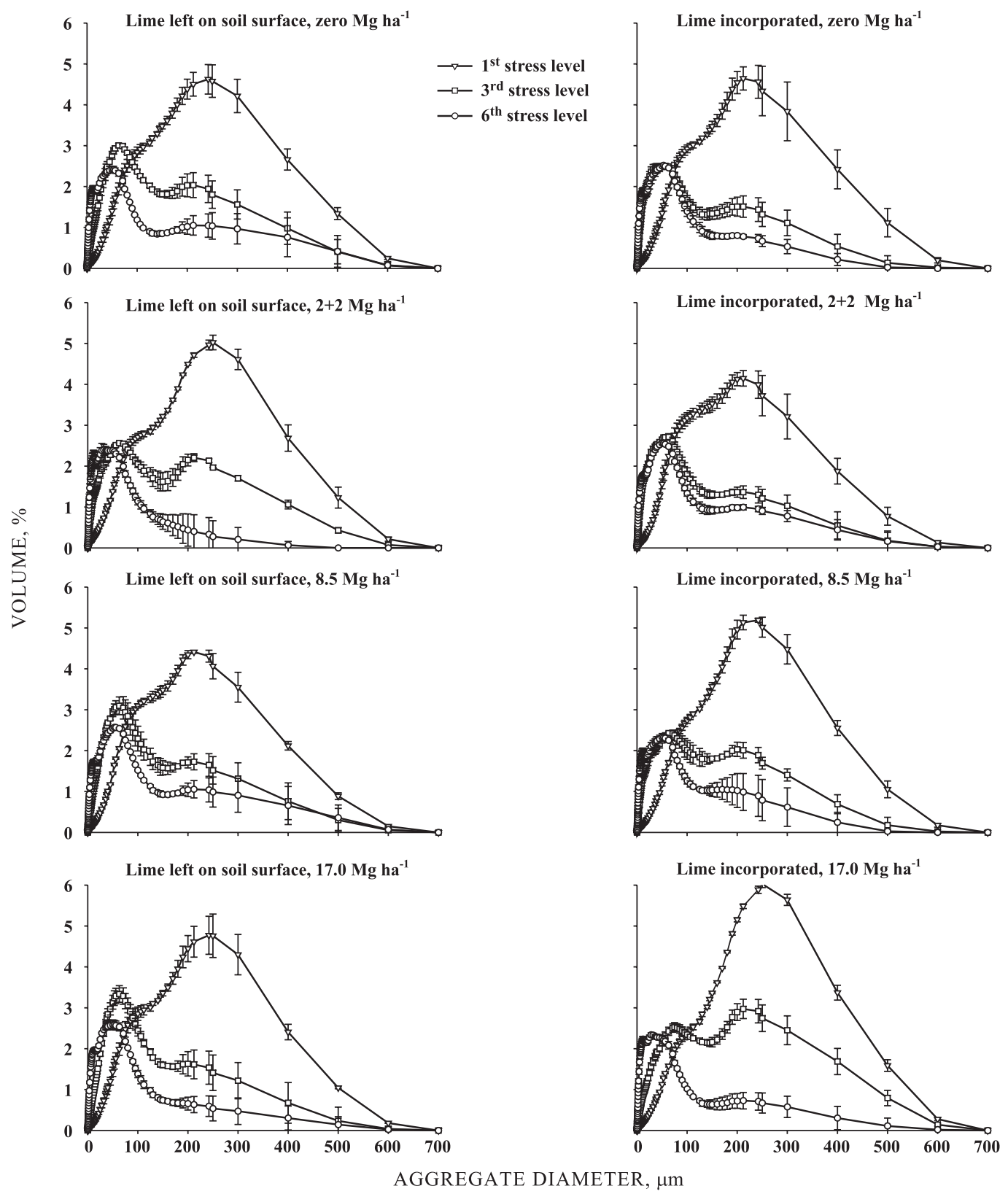

Figure 1. Laser diffraction (DL) diagrams representing aggregates between 1 and 2 mm under stress levels: 1st, immediately after placing the aggregates inside the DL-cell containing deonized water; 3rd, after three minutes of agitation in the presence of $5 \mathrm{~mL}$ of Calgon ${ }^{\circledR}$, and $6 \mathrm{th}$, after three minutes of agitation under ultrasound at $35 \mathrm{~W}$. The samples are from an Acrisol, at 0-0.05 $\mathrm{m}$ of depth, under liming in different doses and forms of application (lime left on soil surface and incorporated). The results are expressed in percent of the aggregate size classes by volume. The vertical bars indicate the mean standard error $(n=3)$.

study the soil structure changes due to soil management practices, including the changes in organic matter contents (Castro Filho et al., 1998). That method uses wet aggregates with a size between 4.76 and $8.00 \mathrm{~mm}$ under slow sieving agitation under water, while the method proposed here suggests microaggregates with a size between 1 and $2 \mathrm{~mm}$ under the presence of water, in addition to using a small initial mass of aggregates.

\section{Effect of stress level, lime doses and forms on soil aggregate stability}

In the first stress (1st), lime left on the soil surface presented modal diameter aggregates between 212 and $246 \mu \mathrm{m}$ (average of $238 \mu \mathrm{m}$ ), while the incorporated lime presented very similar values, between 212 and $250 \mu \mathrm{m}$ (average of $229 \mu \mathrm{m}$ ) (Figure 1). However, when the lime doses were increased, the modal diameter of the aggregates tended to increase, 
especially for incorporated lime. This suggests that soil under liming presents more stable aggregates in the soil water stability test. This is consistent with Haynes \& Naidu (1998) and Pernes-Debuyser \& Tessier (2004), who observed that soil with high $\mathrm{pH}$ due to lime application presented a greater quantity of aggregates larger than $50 \mu \mathrm{m}$ than with other nutrient sources tested.

Regarding the stability indexes (Table 3), the MWD and ASI differed with stress levels, following the tendency of the modal diameter of aggregates reported in figure 1. MWD values decreased from $14.37 \mu \mathrm{m}$, in the first stress level, to $4.94 \mu \mathrm{m}$, in the sixth stress level (Table 3). The MWD diminished from the first to the fourth stress level, however it stabilized in the last three levels. Furthermore, the aggregate stability index (ASI) varied from $67.52 \%$ in the first stress applied to $15.50 \%$ in the sixth stress, similar to the MWD, i.e. the aggregate stability diminished up to the fourth stress applied; however, it stabilized in the last three. Note that the observations in LD were very much reproduceable, confirmed by the low values for the coefficient of variation (Table 3) as well as by the short vertical bars (Figure 1). This suggests that the ASi obtained in LD measurements coherently represent soil micro-aggregate stability. It is probably due to the tests having been made on smaller aggregates that they tend to show intrinsic particle properties, such as cohesion (Le Bissonnais, 1996; Amézketa et al., 2003).
Regarding the forms of lime application, there was no difference in the aggregate stability indexes (MWD and ASI) between the lime left on the soil surface and the lime incorporated (Table 3). These findings suggest that soil management under a no-till system for 12 years after liming, enabled the soil to reduce the effects of the disorder in the physical properties of the soil caused by the incorporation of lime. This interpretation is consistent with those reached by Silva et al. (2000), Lima et al. (2006) and Tavares Filho et al. (2006).

A statistical interaction was observed between lime doses and lime application forms for the MWD $(p=0.065)$ and ASI $(p=0.069)$. More precisely, when lime left on the soil surface, without being incorporated, presented no significant differences for these properties (Table 3 ). It is likely that the lime, after being dissociated in its base $\left(\mathrm{OH}^{-}\right)$and cations $\left(\mathrm{Ca}^{2+}\right.$ or $\left.\mathrm{Mg}^{2+}\right)$, acts as an agent of soil particle aggregation or cementation (Haynes \& Naidu, 1998; Pernes-Debuyser \& Tessier, 2004), especially where it had been incorporated $(0-0.20 \mathrm{~m})$. This interpretation is supported by observations made by Haynes \& Naidu (1998), as well as the correlation among soil chemical properties, i.e. CEC and exchangeable cations and micro-aggregation of the soil. A positive relationship was found between MWD values and the sum of bases $(r=0.52)$; whereas it was the inverse with $\mathrm{CEC}_{7}(\mathrm{r}=-0.57)$. The same tendency is also observed for ASI when the lime is

Table 3. Mean values of the weighted diameter (MWD) and the aggregate stability index (ASI) calculated at each stress level. The samples are aggregates between 1 and $2 \mathrm{~mm}$ of an Acrisol at 0-0.05 $\mathrm{m}$ of depth under liming in different doses and forms of application (lime left on the soil surface and incorporated)

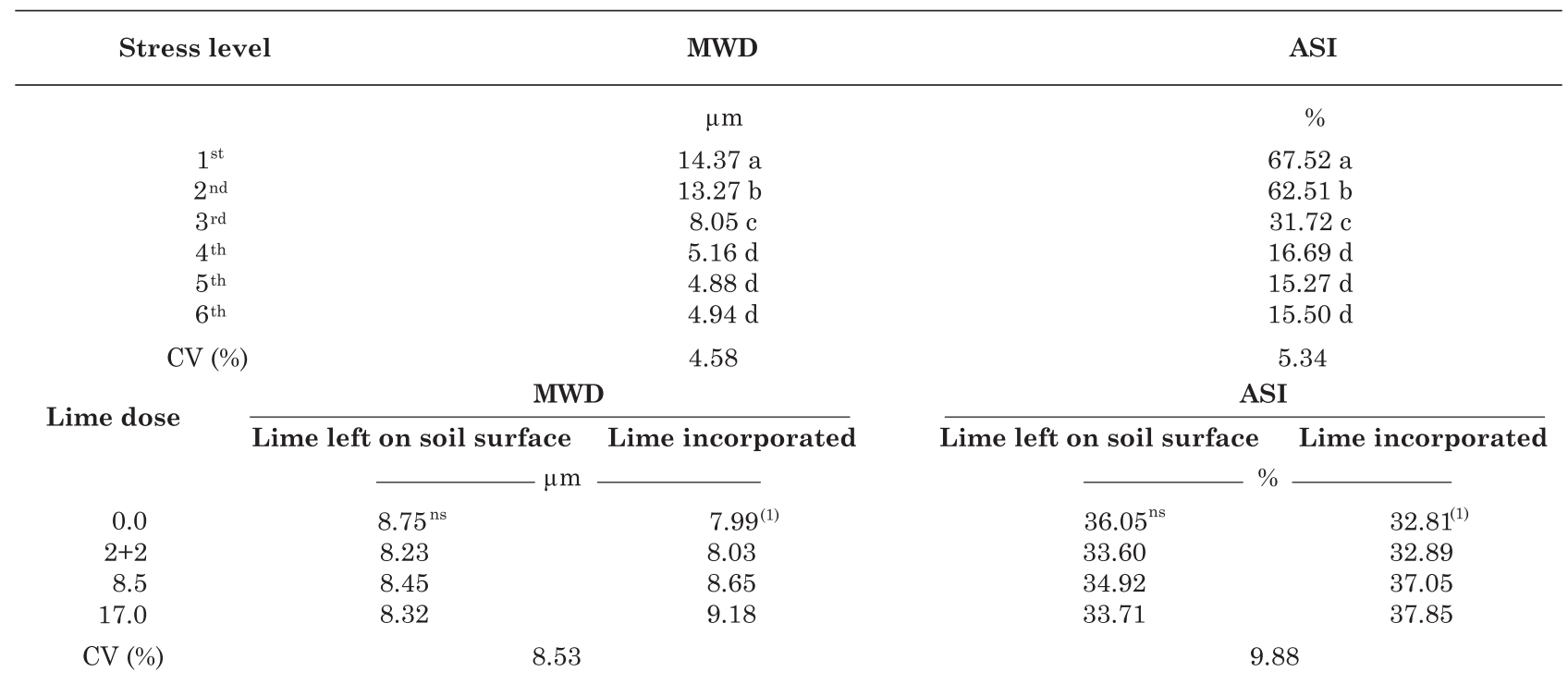

\footnotetext{
${ }^{(1)}$ Indicate needs of the regression analysis, means from quantitative treatment statistically significant. Means followed by the same letter in the given column are not statistically different (Tukey, $p<0.05$ ). CV is the coefficient of variation expressed in percent; $\mathrm{ns}$ is not significant at $\mathrm{p}<0.05$ in variance analysis.
} 
incorporated in the soil. These findings are in accordance with interpretations found in the literature (Prost et al., 1998; Amézketa et al., 2003; PernesDebuyser \& Tessier, 2004; Bortoluzzi et al., 2008a). Thus, the increase in values of chemical properties due to lime incorporation in the soil promotes greater soil aggregation.

However, this effect could not be verified when the lime was kept on the surface, because there is not a total dissolution of the lime on the surface, especially in the larger doses, due to a high $\mathrm{pH}$ in the first centimeters of the soil surface. This understanding is confirmed by Rheinheimer et al. (2000), who perceived that the corrective effect of lime only occurs when lime on the surface is dissolved at $\mathrm{pH}$ values $<5.3$, when studying the dissolution of lime. The effects of the lime doses on aggregation are limited when the lime is kept on the surface, since most of the doses do not present complete dissolution of the lime, which is reflected in the MWD and ASI. It is interesting to note that the relationship between the soil stability indexes and the chemical soil properties are inverted, in comparison with those found in incorporated lime. The MWD and ASI for the treatment, when lime was left on the soil surface, presented coefficients of correlation for the sum of bases of $r=-0.83$ and $r=-0.93$, respectively and for $\mathrm{CEC}_{7}$ of $\mathrm{r}=0.89$ and $\mathrm{r}=0.83$, respectively. This can be explained as a response to an excess dosage of lime on the soil surface (17 $\left.\mathrm{Mg} \mathrm{ha}^{-1}\right)$, as it is approximately four times higher than the dose recommended for notill on the soil surface (CQFSRS/SC, 2004).

Considering the mean of the six stress levels for the MWD and ASI variables, it can be seen that there was a significant response to the lime doses when incorporated in the soil (Figure 2). Figure 2 shows the relationship between MWD and ASI as a function of lime doses when they were incorporated in the soil. MWD and ASI values increased together with the increase in lime doses. This increase is regulated for the MWD and ASI, respectively, by the linear expressions: $\hat{y}=7.96+0.0728 x$, with $R^{2}=0.986$ $(p<0.05)$ and, $\hat{y}=32.95+0.323 x$, with $R^{2}=0.876$ $(\mathrm{p}<0.05)$. There was an increase of MWD and ASI values, respectively of around $0.07 \mu \mathrm{m}$ and $0.3 \%$ for each $1,000 \mathrm{~kg}$ of lime applied.

In summary, even after 12 years of lime application, it is still possible to visualize the effects of liming on chemical properties, as was also reported by Kaminski et al. (2005). As expected, the soil chemical properties presented that, in general, an increase in the lime doses increases the values of $\mathrm{pH}$, $\mathrm{Ca}, \mathrm{Mg}$ and $\mathrm{CEC}_{\mathrm{E}}$, especially when lime is left on the soil surface (Table 1). These findings corroborate our hypothesis, suggesting that the electrochemical condition of the soil due to liming affects soil microaggregation, in addition to factors found in the literature such as soil mineralogy, soil texture, soil
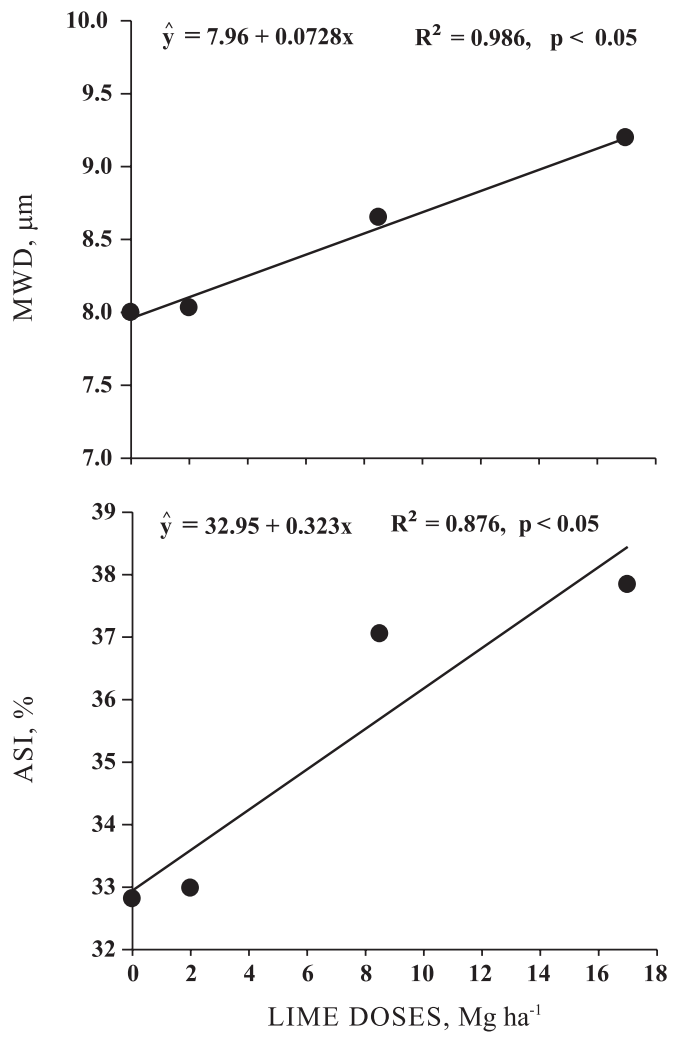

Figure 2. Mean values of the Mean Weighted Diameter (MWD) and the Aggregate Stability Index (ASI) from aggregates between 1 and $2 \mathrm{~mm}$ of an Acrisol at 0-0.05 $\mathrm{m}$ of depth as a function of doses of incorporated lime. Each value represents the mean of six stress levels in LD and two lime forms.

organic matter contents and soil management (Le Bissonnais, 1996; Muggler et al., 1997; Griève, et al., 2005; Veiga et al., 2009). Changes in the soil aggregation process in small scale studied by laser diffraction as a response to soil electrochemistry can be considered an advance in studies of physical properties, as reported by Haynes \& Naidu (1998). Thus, this work contributes to a better understanding of the effects from the electrochemistry of the soil as a result of liming on the aggregation of an Acrisol. This indicates that liming must be considered as a practice which promotes extensive alterations in the soil, not only on its chemical properties, but also on its physical properties, as also suggested by Bortoluzzi et al. (2008a).

\section{CONCLUSIONS}

1. The laser diffraction (LD) method explains in detail the micro-aggregation of an Acrisol, while the traditional method of macro-aggregates has not been able to. The pre-treatments in LD including agitation 
forces and a chemical dispersant are able to discriminate the modal aggregate sizes in tests.

2. The form of lime application did not provide changes in macro- and micro-aggregation indexes, i.e. MWD and ASI. However, changes in soil electrochemistry, due to lime doses incorporated in the soil, promote great micro-aggregate stability, demonstrating that soil chemical properties are linked to soil micro-aggregation.

\section{ACKNOWLEDGEMENTS}

The authors thank EMBRAPA-Trigo and IPHUFRGS for their support, as well as the Fundação de Amparo à Pesquisa do Estado do Rio Grande do Sul (FAPERGS) for the BIC fellowship granted. E.C. Bortoluzzi received CNPq research fellowship

\section{LITERATURE CITED}

ALBUQUERQUE, J.A.; BAYER, C.; ERNANI, P.R.; MAFRA, A.L. \& FONTANA, E.C. Aplicação de calcário e fósforo e estabilidade da estrutura de um solo ácido. R. Bras. Ci. Solo, 29:799-806, 2003.

AMÉZKETA, E.; ARAGÜÊS, R.; CARRANZA, R. \& URGEL, B. Macro- and micro-aggregate stability on soils determined by a combination of wet-sieving and laserray diffraction. Spanish J. Agric. Res., 1:83-94, 2003.

BEEKMAN, A.; SHAN, D.; ALI, A.; DAI, W.; WARD-SMITH, S. \& GOLDENBERG, M. Micrometer scale particle sizing by laser diffraction: Critical impact of the imaginary component of refractive index. Pharmac. Res., 22:518$522,2005$.

BORTOLUZZI, E.C.; GARBOZZA, L.; GUARESCHI, C. \& RHEINHEIMER, D.S. Efeito da calagem na relação entre solo e água. R. Bras. Ci. Solo, 32:2621-2628, 2008 a.

BORTOLUZZI, E.C.; PERNES, M. \& TESSIER, D. Mineralogia de partículas envolvidas na formação de gradiente textural em um Argissolo subtropical. R. Bras. Ci. Solo, 32:997$1007,2008 b$.

BORTOLUZZI, E.C. \& POLETO, C. Metodologias para estudos de sedimentos: ênfase na proporção e na natureza mineralógica das partículas. In: MERTEN, G.H. \& POLETO, C., orgs. Qualidade de sedimentos. Porto Alegre, ABRH, 2006. p.80-140.

CASTRO FILHO, C.; MUZILLI, O. \& PODANOOSCHI, A.L. Estabilidade dos agregados e sua relação com o teor de carbono orgânico num Latossolo Roxo distrófico, em função de sistemas de plantio, rotações de culturas e métodos de preparo das amostras. R. Bras. Ci. Solo, 22:527538, 1998.

CHAPLAIN, V.; BRAULT, A.; TESSIER, D. \& DÉFOSSEZ, P. Soil hydrophobicity: A contribution of diuron sorption experiments. Europ. J. Soil Sci., 59:1202-1208, 2008.
COMISSÃO DE QUÍMICA E FERTILIDADE DO SOLO DO RIO GRANDE DO SUL E DE SANTA CATARINA CQFSRS/SC. Manual de adubação e de calagem para os estados do Rio Grande do Sul e Santa Catarina. 10 ed. Porto Alegre, SBCS-Núcleo Regional Sul, 2004. 400p.

COSTA, F.S.; BAYER, C.; ALBUQUERQUE, J.A. \& FONTOURA, S.M.V. Calagem e as propriedades eletroquímicas e físicas de um Latossolo em plantio direto. Ci. Rural, 34:281-284, 2004.

DUR, J.C.; ELSASS, F.; CHAPLAIN, V. \& TESSIER, D. The relationship between particle-size distribution by laser granulometry and image analysis by transmission electron microscopy in a soil clay fraction. Europ. J. Soil Sci., 55:265-270, 2004.

EMPRESA BRASILEIRA DE PESQUISA AGROPECUÁRIA EMBRAPA. Centro Nacional de Pesquisa de Solos. Manual de métodos de análises dos solos. 2.ed. Rio de Janeiro, 1997. 212p.

EMPRESA BRASILEIRA DE PESQUISA AGROPECUÁRIA EMBRAPA. Sistema brasileiro de classificação de solos. 2.ed. Brasília, 2006. 306p.

FAO. World reference base for soil resources - WRB. 2.ed. Roma, FAO, 2006. 145p. (World Soil Resources Reports, 103)

GRIÈVE, I.C.; DAVIDSON, D.A. \& BRUNEAU, P.M.C. Effects of liming on void space and aggregation in an upland grassland soil. Geoderma, 125:39-48, 2005.

HAYNES, R.J. \& NAIDU, R. Influence of lime, fertilizer and manure applications on soil organic matter content and soil physical conditions: A review. Nutr. Cycling Agriecosyst., 51:123-137, 1998.

HSIEH, Y.P. Using clay mineralogy to infer sources of suspended clay and silt in a watershed: Quantitative approach. Soil Sci. Soc. Am. J., 48:1446-1450, 1984.

KAMINSKI, J.; RHEINHEIMER, D.S.; GATIBONI, L.C.; BRUNETTO, G. \& SILVA, L.S. Eficiência da calagem superficial e incorporada precedendo o sistema plantio direto em um Argissolo sob pastagem natural. R. Bras. Ci. Solo, 29:573-580, 2005.

KEMPER, W.D. \& CHEPIL, W.S. Size distribution of aggregates. In: BLACK, C.A.; EVANS, D.D.; WHITE, J.L.; ENSMINGER, L.E. \& CLARK, F.E., eds. Methods of soil analysis - Physical and mineralogical properties, including statistics of measurement and sampling. Madison, American Society of Agronomy, 1965. p.499-510. (Agronomy Series, 9)

LE BISSONNAIS, Y. Aggregate stability and measurement of soil crustability and erodibility. I. Theory and methodology. Europ. J. Soil Sci., 47:425-437, 1996.

LIMA,C.L.R.; REINERT, D.J.; REICHERT, J.M.; SUZUKI, L.E.A.S. \& GUBIANI, P.I. Qualidade físico-hídrica e rendimento de soja (Glycine $\max$ L.) e feijão (Phaseolus vulgaris L.) de um Argissolo Vermelho distrófico sob diferentes sistemas de manejo. Ci. Rural, 36:1172-1178, 2006. 
MONNIER, G.; STENGEL, P. \& FIES, J.C. Une méthode de mesure de la densité apparente de petits agglomérats terreux: Application à l'analyse des systèmes de porosité du sol. Ann. Agron., 24:533-545, 1973.

MOREnO, J.A. Clima do Rio Grande do Sul. Porto Alegre, Secretaria de Agricultura, 1961. 42p.

MUDROCH, A.; AZCUE, J. \& MUDROCH, P. Manual of physico-chemical analysis of aquatic sediments. Boca Raton, CRC Press, 1996. 287p.

MUGGLER, C.C.; PAPE, T. \& BUURMAN, P. Laser grain-size determination in soil genetic studies. 2. Clay content, clay formation, and aggregation in some Brazilian Oxisols. Soil Sci., 162:219-228, 1997.

PERNES-DEBUYSER, A. \& TESSIER, D. Soil physic properties affected by long term fertilizer. Europ. J. Soil Sci., 55:505$512,2004$.

POLETO, C.; BORTOLUZZI, E.C.; CHARLESWORTH, S.M. \& MERTEN, G.H. Urban sediment particle size and pollutants in Southern Brazil. J. Soils Sediments, 9:317 $327,2009$.

POLETO, C.; BORTOLUZZI, E.C. \& MERTEN, G.H. Uso de ultra-som como pré-tratamento de amostras de sedimento fluvial em difratometria laser. In: MERTEN, G.H.; POLETO, C. \& BORGES, A.L.O., orgs. Sedimentos: O desafio da multidisciplinaridade. Porto Alegre, ABRH, 2007. p.51-66.

PROST, R.; KOUTIT, T.; BENCHARA, A. \& HUARD, E. State and location of water adsorbed on clay minerals: Consequences of the hydration and swelling-shrinkage phenomena. Clays Clay Miner., 46:117-131, 1998.

REICHERT, J.M.; LIMA, C.L.R.; DALMOLIN, R.S.D.; REINERT, D.; GONÇALVES, C. \& NUNES, M. Agregação de um Planossolo sistematizado há um ano e sob cultivo de arroz irrigado. Ci. Rural, 36:837-844, 2006.

REICHERT, J.M.; REINERT, D.J. \& BRAIDA, J.A. Qualidade dos solos e sustentabilidade de sistemas agrícolas. Ci. Amb., 27:29-48, 2003.
RHEINHEIMER, D.S.; SANTOS, E.J.S.; KAMINSKI, J.; BORTOLUZZI, E.C. \& GATIBONI, L.C. Alteração de atributos do solo pela calagem superficial e incorporada a partir de pastagem natural. R. Bras. Ci. Solo, 24:797-805, 2000.

SILVA, I.F. \& MIELNICZUK, J. Sistemas de cultivo e características do solo afetando a estabilidade de agregados. R. Bras. Ci. Solo, 22:311-317, 1998.

SILVA, V.R.; REINERT, D.J. \& REICHERT, J.M. Resistência mecânica do solo à penetração influenciada pelo tráfego de uma colhedora em dois sistemas de manejo do solo. Ci. Rural, 30:795-801, 2000.

UNITED STATES DEPARTMENT OF AGRICULTURE USDA. Soil Survey Staff. Soil taxonomy: A basic system of soil classification for making and interpreting soil surveys. 2 ed. Washington, U.S. Department of Agriculture, Natural Resources Conservation Service, Soil Survey Staffa, 1999. 871p. (Agriculture Handbook, 436)

SORATTO, R.P. \& CRUSCIOL, C.A.C. Atributos químicos do solo decorrentes da aplicação em superfície de calcário e gesso em sistema plantio direto recém-implantado. R. Bras. Ci. Solo, 32:675-688, 2008.

SOUZA, Z.M.; MARQUES JR, J.; PEREIRA, G.T. \& SÁENZ, C.M.S. Spatial variability of aggregate stability in Latosols under sugarcane. R. Bras. Ci. Solo, 33:245-254, 2009.

TAVARES-FILHO, J.; FONSECA, I.C.B.; RIBON, A.A. \& BARBOSA, G.M.C. Efeito da escarificação na condutividade hidráulica de um Latossolo Vermelho sob plantio direto. Ci Rural, 36:996-999, 2006.

TEDESCO, M.J.; GIANELLO, C.; BISSANI, C.A.; BOHNEN, H. \& VOLKWEISS, S.J. Análise de solo, plantas e outros materiais. 2.ed. Porto Alegre, Universidade Federal do Rio Grande do Sul, 1995. 174p.

VEIGA, M.; REINERT, D.J.; REICHERT, J.M. \& KAISER, D.R. Short and long-term effects of tillage systems and nutrient sources on soil physical properties of a southern Brazilian Hapludox. R. Bras. Ci. Solo, 32:1437-1446, 2008.

YODER, R. A direct method of aggregate analysis of soils and a study of the physical nature of erosion losses. J. Am. Soc. Agron., 28:337-435, 1936. 